\title{
Pyrrovobasine, hybrid alkylated pyrraline monoterpene indole alkaloid pseudodimer discovered using a combination of mass spectral and NMR-based machine learning annotations_
}

\footnotetext{
Hugues Fouotsa ${ }^{\mathrm{DD}} a b c$, Pierre Mkounga ${ }^{c}$, Alain Meli Lannang ${ }^{d}$, Jérôme Vanheuverzwijn ${ }^{b}$, Zhiyu Zhou ${ }^{b}$, Karine Leblanc ${ }^{a}$, Somia Rharrabti ${ }^{a}$, Augustin Ephrem Nkengfack ${ }^{c}$, Jean-François Gallard ${ }^{e}$, Véronique Fontaine ${ }^{b}$, Franck Meyer ${ }^{b}$, Erwan Poupon ${ }^{D} a$, Pierre Le Pogam (iD*a and Mehdi A. Beniddir (iD*a

aÉquipe "Chimie des Substances Naturelles" Université Paris-Saclay, CNRS, BioCIS, 5 rue J.-B. Clément, 92290 Châtenay-Malabry, France. E-mail: pierre.le-pogam-alluard@universite-paris-saclay.fr; mehdi.beniddir@universite-paris-saclay.fr

${ }^{b}$ Faculty of Pharmacy, Microbiology, Bioorganic and Macromolecular Chemistry Unit, Université Libre de Bruxelles, Campus de la PlaineCP 206/04, Boulevard du Triomphe, ACC.2, Po Box 1050, Belgium

'Department of Organic Chemistry, Faculty of Science, University of Yaoundé I, P.O. Box 812, Yaoundé, Cameroon
} 
${ }^{d}$ Department of Chemistry, Higher Teachers Training College, University of Maroua, P.O. Box 55, Maroua, Cameroon

eInstitut de Chimie des Substances Naturelles, CNRS, ICSN UPR 2301, Université Paris-Saclay, 91198 Gif-sur-Yvette, France

Received 12th September 2021, Accepted 27th September 2021

First published on 27th September 2021

\section{Abstract}

A new vobasine-tryptamine-based monoterpene indole alkaloid pseudodimer was isolated from the stem bark of Voacanga africana. As a minor constituent occurring in a thoroughly investigated plant, this molecule was targeted based on a molecular networking strategy and a rational $\mathrm{MS}^{2}$-guided phytochemical investigation led to its isolation. Its structure was formally established based on HRMS, 1D/2D NMR data, and the application of the tool Small Molecule Accurate Recognition Technology (SMART 2.0). Its absolute configuration was assigned by the exciton chirality method and TD-DFT ECD calculations. Besides featuring an unprecedented intermonomeric linkage in the small group of vobasine/tryptamine hybrids, pyrrovobasine also represents the first pyrraline-containing representative in the whole monoterpene indole alkaloids group. Biosynthetic hypotheses possibly underpinning these structural oddities are proposed here.

\section{Introduction}

Fueled by the diverse ethnopharmacological claims related to Voacanga africana Stapf ex Scott-Elliot, decades of intensive phytochemical campaigns unveiled the array of specialized products it shelters with a salient emphasis on its monoterpene indole 
alkaloid (MIA) content. Notwithstanding the long-held interest in V. africana chemistry, new appendages of MIAs are continuously being reported from this plant source. $\underline{\underline{1-3}}$ The tremendous advances in MS2-based data processing strategies and in sensitivity of NMR techniques provide natural product chemists with ever-expanding capabilities for exploration of compounds occurring in minute amounts.,, 5 These refined analytical workflows pave the way for the re-investigation of deeply dug models using a state-of-the-art pipeline to gear the isolation efforts towards so-far overlooked chemical entities. $\frac{6-12}{}$ In the frame of our quest for new MIA-type specialized metabolites, and benefitting from our recent upload to the GNPS spectral libraries of the MIADB, $\underline{13}$ we embarked on a molecular-networking-based phytochemical investigation of $V$. africana stem bark. The observation of a molecular family clustered around a node tentatively tagged as ceridimine, a rare vobasine/tryptamine-type pseudodimer so far only known from Pagiantha cerifera (Pancher \& Sebert) Markgr., $\underline{14}$ sparked our interest and guided us to isolate the newly-reported pyrrovobasine (1) following a MS²streamlined isolation workflow. Besides representing the first instance of vobasine-tryptamine dimer featuring a C-3-C-2' interunit bonding,,$\underline{15}$ pyrrovobasine is also the first pyrraline-containing member in the huge phytochemical class of MIAs.

\section{Results and discussion}

To reach a wide and untargeted insight into the indolomonoterpenic alkaloid content of $V$. africana, both the alkaloid and crude ethanolic extracts of its stem bark were profiled by HPLC-HRMS² (positive polarity). These data were subsequently processed using the classical molecular-networking workflow $\underline{\underline{17}}$ and dereplicated against the MIADB-implemented GNPS spectral libraries. A cautious examination of the obtained molecular network (Fig. S1I) highlighted a molecular family consisting of four nodes (Fig. S2士) instigating a connection with a central node tentatively tagged as ceridimine. This constellation held a peculiar signifiance as only very few derivatives of ceridimine, $\underline{\underline{14}}$ pertaining to the rare phytochemical class of vobasine-tryptamine pseudodimers, have been reported so far with none being consistent with the currently disclosed nominal masses. With this in mind, the LC-DAD-MS profile related to the alkaloidal extract of $V$. africana was monitored to check which of these compounds could be isolated in sufficient yield for full structure elucidation, leading us to guide our 
isolation efforts towards the ion detected at $m / z$ 605.303. Notwithstanding its relatively elevated molecular mass, the mass spectrum of this compound lacked the diagnostic isotopic pattern for doubly charged ion species encountered in most dimeric monoterpene indole alkaloids. This observation hinted that this molecule comprises a unique basic site, which strengthened our interest in isolating it. The molecular formula retrieved from this mass spectrometric signal, $\mathrm{C}_{37} \mathrm{H}_{40} \mathrm{~N}_{4} \mathrm{O}_{4}$, returned no hit in the Dictionary of Natural Products, $\underline{18}$ deftly convincing us to undertake its $\mathrm{MS}^{2}$-streamlined isolation.

Compound $\mathbf{1}$ (Fig. 1 ) was isolated from the alkaloidic extract of $V$. africana stem bark by repetitive chromatographic separations following a MS²-guided phytochemical pipeline. Obtained as a brown amorphous solid, its molecular formula was confirmed to be $\mathrm{C}_{37} \mathrm{H}_{40} \mathrm{~N}_{4} \mathrm{O}_{4}$ based on the protonated molecular ion at $m / z 605.3122$ (calcd for $\mathrm{C}_{37} \mathrm{H}_{41} \mathrm{~N}_{4} \mathrm{O}_{4}, 605.3122$ ), indicating 20 degrees of hydrogen deficiency. The cursory examination of the NMR data of 1 revealed NMR landmarks evocative of a 3-vobasinyl unit. 19 Accordingly, the ${ }^{1} \mathrm{H}$ and ${ }^{13} \mathrm{C}$ NMR data of 1 showcased the presence of four aromatic resonances, an upfield-shifted methyl ester group $\left(\delta_{\mathrm{H}} 2.49 / \delta_{\mathrm{C}} 169.2\right.$; 51.0), an $N_{4}$-Me group $\left(\delta_{\mathrm{H}} 2.89 / \delta_{\mathrm{C}} 40.5\right)$ and an ethylidene side chain $\left(\delta_{\mathrm{H}} 5.60 / \delta_{\mathrm{C}} 126.6 ; \delta_{\mathrm{H}} 1.73 / \delta_{\mathrm{C}} 13.0\right)$. Alongside the crosspeaks related to the contiguous aromatic hydrogens of the indole core, the COSY spectrum confirmed the occurrence of an isolated aminomethylene

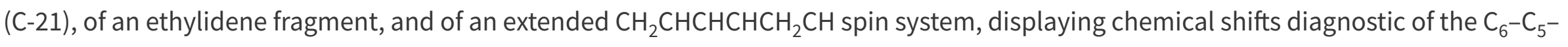
$\mathrm{C}_{16}-\mathrm{C}_{15}-\mathrm{C}_{14}-\mathrm{C}_{3}$ appendage of a vobasine-type MIA, further validated by the key HMBC crosspeaks outlined in $\underline{\text { Fig. }}$. $2 \mathrm{~B}$. The shielded chemical shift of the ester methyl linked to $\mathrm{C}-16$ placed it within the shielding zone of the indole nucleus. $\underline{6}$ 


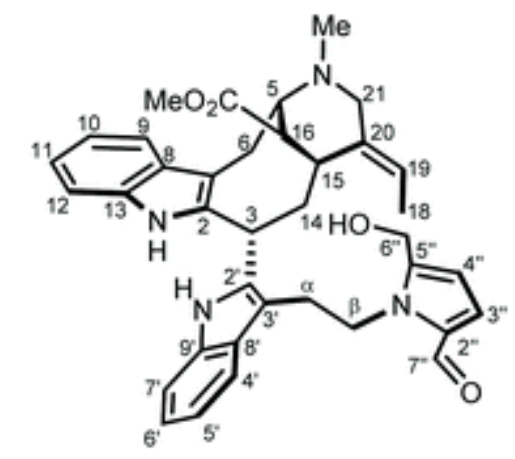

Fig. 1 Chemical structure of pyrrovobasine (1).
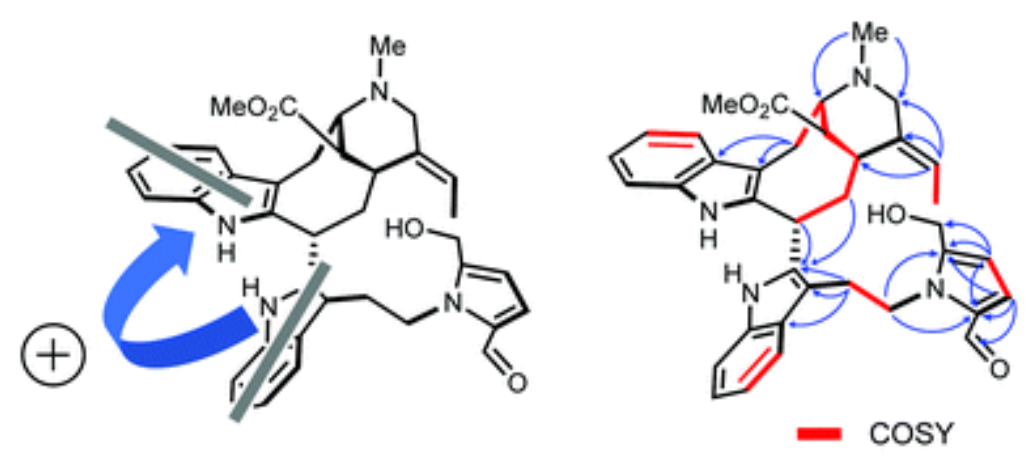

Fig. 2 (A) Two electronic dipoles denoting a positive chirality. (B) Selected 2D NMR correlations for 1.

Consistent with the molecular network which determined $\mathbf{1}$ as a close derivative of ceridimine, the remaining signals hinted the occurrence of an additional free side chain-bearing tryptamine unit. Four additional resonances related to aromatic/olefinic protons substantiated this assumption, as well as the two vicinal methylenic protons that determined a $\mathrm{CH}_{2} \mathrm{CH}_{2} \mathrm{~N}$ fragment. The structural 
elements elucidated so far determined $\mathbf{1}$ as a vobasine-tryptamine pseudodimer. This small phytochemical class is so far represented by three molecules, all obtained from an apocynaceous source: ceridimine (from $P$. cerifera), $\underline{14}$ demethylceridimine (from the by-then Peschiera buchtienii (H.J.P.Winkl.) Markgr., 20 now known as Tabermaemontana cymosa Jacq.), and hunteriatryptamine (from Hunteria zeylanica (Retz.) Gardner ex Thwaites). $\underline{21}$ All these closely related molecules featured a linkage between the C-3 position of the vobasinyl residue to the $\mathrm{C}-6^{\prime}$ site of the tryptamine component. Regarding 1 , the $\mathrm{HMBC}$ correlations from the protons resonating at $\delta_{\mathrm{H}} 2.02(\mathrm{H}-14)$, at $\delta_{\mathrm{H}} 4.87(\mathrm{H}-3)$, and at $\delta_{\mathrm{H}} 3.42\left(\mathrm{H}_{2}-\alpha\right)$ to $\mathrm{C}-2^{\prime}\left(\delta_{\mathrm{C}} 137.9\right)$ were diagnostic of a so-far unprecedented $\mathrm{C}-3-\mathrm{C}-2^{\prime}$ connection between the vobasine and tryptamine units. The $\beta$-orientation of $\mathrm{H}-3$ was established based on the magnitude of the coupling constant values (dd, $\mathrm{J}=13.4,2.7$ $\mathrm{Hz}$ ), in excellent agreement with former literature reports. $\underline{22}$

At this stage of the structure elucidation process, a few signal patterns were still pending assignment: two contiguous aromatic/olefinic protons disclosing an unusual coupling constant value of $3.9 \mathrm{~Hz}\left[\delta_{\mathrm{H}} 6.97(1 \mathrm{H}, \mathrm{d}, J=3.9 \mathrm{~Hz}) / \delta_{\mathrm{C}} 124.3 ; \delta_{\mathrm{H}} 6.30(1 \mathrm{H}, \mathrm{d}, J=\right.$ $\left.3.9 \mathrm{~Hz}) / \delta_{\mathrm{C}} 110.7\right]$, a shielded aldehydic proton $\left[\delta_{\mathrm{H}} 9.56(1 \mathrm{H}, \mathrm{s}) / \delta_{\mathrm{C}} 179.9\right]$, a set of oxygenated methylenic protons $\left[\delta_{\mathrm{H}} 4.63(1 \mathrm{H}, \mathrm{d}, J=13.5\right.$ $\mathrm{Hz})$ and $\left.4.77(1 \mathrm{H}, \mathrm{d}, J=13.5 \mathrm{~Hz}) / \delta_{\mathrm{C}} 56.7\right]$, and finally two low-field shifted quaternary carbons $\left(\delta_{\mathrm{C}} 141.9\right.$ and 132.9$)$. To expedite the elucidation of this specific fragment, the HSQC data retrieved from it were collated in a .csv file prior to being uploaded into the SMART 2.0 (Small Molecule Accurate Recognition Technology) platform. This artificial intelligence-based tool is used to generate structure hypotheses from HSQC data through a deep convolutional neural network architecture that includes the ${ }^{1} \mathrm{H}-{ }^{13} \mathrm{C} H S Q C$ spectra related to more than 53000 natural products (encompassing approximately 15\% of the known natural products as of 2020). $\underline{23}, \underline{24}$ SMART analysis revealed 5-(hydroxymethyl)pyrrole-2-carbaldehyde, or pyrraline, to be the preferred hit (cosine value $\approx 0.97$ ), guiding us to consider it to account for the so far unassigned structural elements. Accordingly, SMART assistance tended to elucidate the structure of 1 as indicated in Fig. 1, in good agreement with molecular formula requirements. The key HMBC correlations outlined in Fig. 2B confirmed this tentative structure as the nitrogen atom of the pyrrole nucleus was shown to correspond to that of the side chain of the tryptamine unit, as evidenced based on the HMBC correlations from the protons resonating at $\delta_{\mathrm{H}} 4.84\left(\mathrm{H}_{2}-\beta\right)$ to both $\mathrm{C}-2^{\prime \prime}\left(\delta_{\mathrm{C}} 132.9\right)$ and $\mathrm{C}-5^{\prime \prime}\left(\delta_{\mathrm{C}} 141.9\right)$. A 
rapid literature survey indicated that pyrraline-containing natural products display highly similar chemical shifts values, also for aromatic quaternaries left unconsidered throughout SMART analyses. $\underline{25}$ The absolute configuration of $\mathbf{1}$ was determined using the exciton chirality $\mathrm{CD}$ method. $\underline{26}$ The positive sign of the first Cotton effect $\left[\lambda_{\max } 237 \mathrm{~nm}(\Delta \varepsilon+31)\right]$ and the negative sign of the second one $\left[\lambda_{\max } 222 \mathrm{~nm}(\Delta \varepsilon-\right.$ 21)] (Fig. 3 ) indicated a right-handed screw between the two indole chromophores (Fig. $2 \mathrm{~A}) . \underline{27}$ The good fit between the calculated ECD spectrum of the lowest-energy conformer of 1 and the experimental ECD spectrum confirmed the proposed absolute configuration (Fig.

3). These structural features allowed to elucidate the structure of $\mathbf{1}$, namely pyrrovobasine, as shown in Fig. 1.

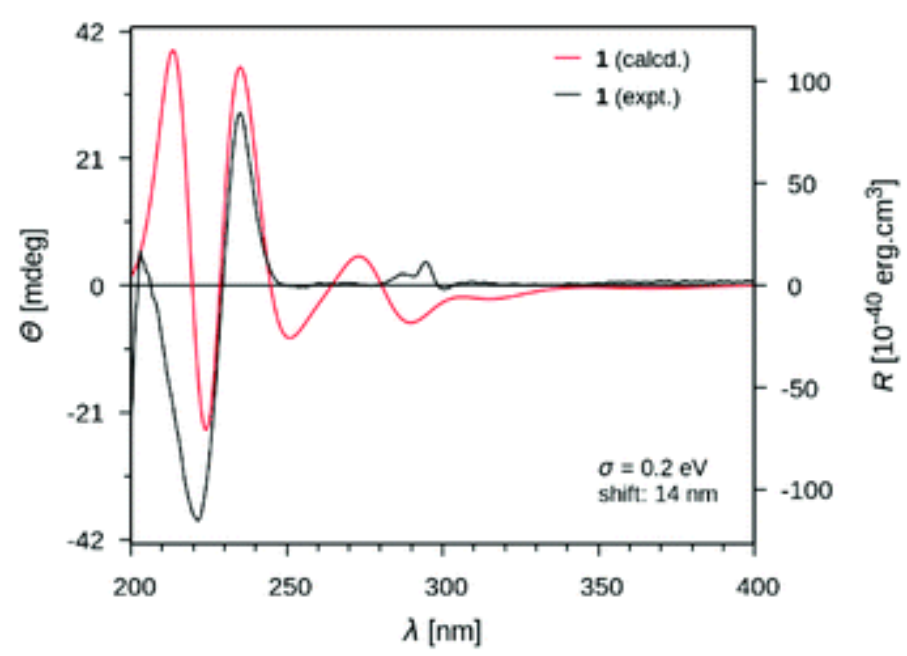

Fig. 3 ECD spectra of 1 (experimental and calculated at the B3LYP/6-31G* level).

Pyrrovobasine features several structural oddities which are worth being stressed out. As already pinpointed, the nature of the connection between the tryptamine and the vobasine subunits meets no precedents in this small group of pseudodimers. The electrophilic nature of vobasinol C-3 (Fig. 4 ) is illustrious and, as such, dimeric MIA structures disclosing a 3-vobasinyl residue following its 
attack by an electron-rich center are of considerable generality. $\underline{15}$ As per the tryptamine component, a literature survey indicates that an array of different substituents can be encountered at a tryptaminic C-2 position such as prenyl groups, $\underline{28}$ bromine atoms, $\underline{29}$ methyl groups,,$\frac{30}{}$ a beta-carboline,, 31 or may even lead to disulfide-bonded dimeric structures. $\frac{32}{2}$ The depiction of the resonance contributors related to the indolic system reveals that all non-bridgehead carbons can serve as functional carbanion equivalents. $\underline{33,34}$

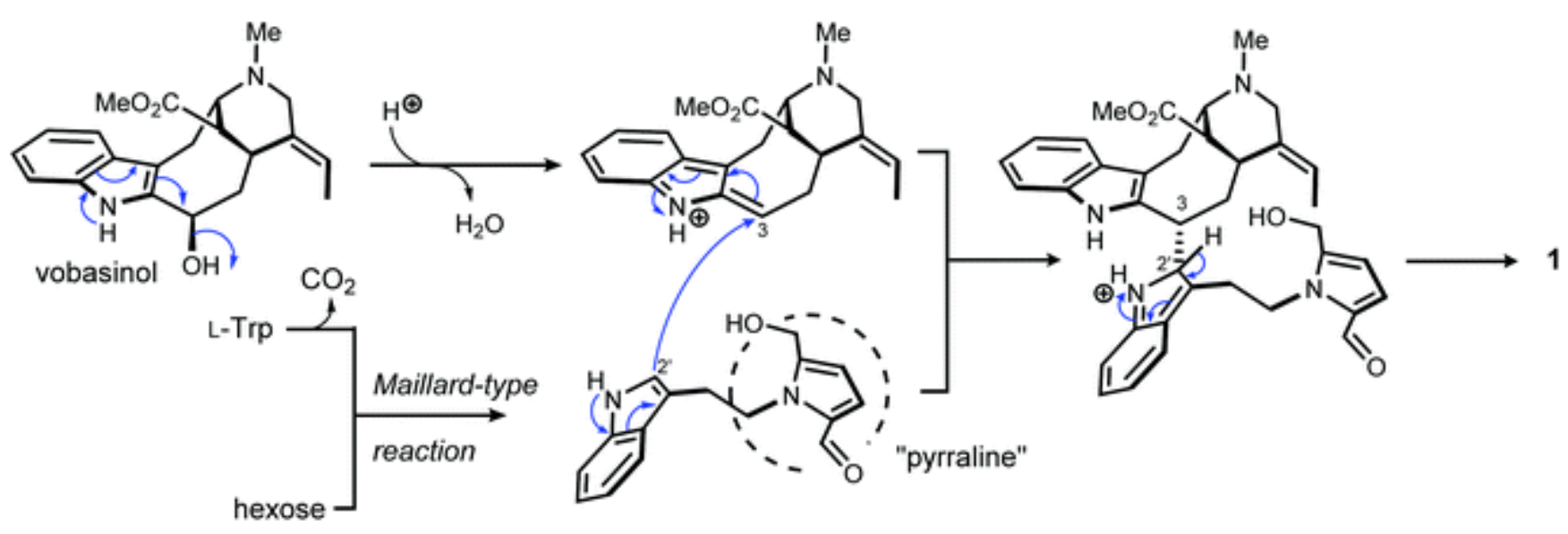

Fig. 4 Possible biosynthetic logic of pyrrovobasine (1).

At last, 5-hydroxymethylpyrrole-2-carbaldehyde, sometimes referred to as pyrraline, is known from a wealth of natural sources, but also from cooked foods. $\frac{35}{}$ No enzymatic biosynthetic pathway to this nucleus has been proposed so far and it is rather believed that this

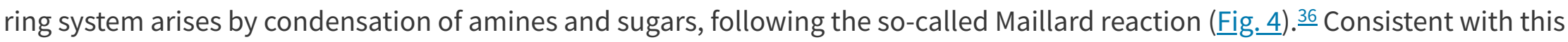
viewpoint, 2-formylpyrrole-containing natural substances are ubiquitous in nature and these molecules - recently reviewed by Brimble et al. are classified based on the nature of their amine component, falling into three major types: amino acids, biogenic amines or amino 
sugars. $\frac{35}{5}$ Tryptamine-based pyrrole alkaloids have already been reported from macromycetes in particular. $\underline{37}, \underline{38}$ Yet, to the best of our knowledge, pyrrovobasine represents the first example of pyrraline-containing monoterpene indole alkaloid.

The in vitro antibacterial activities of compound $\mathbf{1}$ were evaluated against Mycobacterium smegmatis, M. abscessus, M. bovis BCG, Staphylococcus aureus and Pseudomonas aeruginosa. The results showed that pyrrovobasine (1) exerts no antibacterial activity (MIC > $\left.50 \mu \mathrm{g} \mathrm{mL} \mathrm{m}^{-1}\right)$.

\section{Conclusions}

In summary, we have described the first member of the pyrrovobasine family of natural products from the stem bark of $V$. africana, representing the first example of a pyrraline-containing monoterpene indole alkaloid. The isolation process was enabled by exploiting a molecular networking approach and the structure elucidation was assisted by an NMR-based machine learning tool.

\section{Experimental section}

\section{General experimental procedures}

Optical rotations were measured at $25^{\circ} \mathrm{C}$ on a Polaar 32 polarimeter. UV spectra were recorded on a Lightwave II + WPA 7126 V. 1.6.1 spectrophotometer. ECD spectra were measured at $25^{\circ} \mathrm{C}$ on a JASCO J-810 spectropolarimeter. IR spectra were recorded with a PerkinElmer type 257 spectrometer. The NMR spectra were recorded on a Bruker AM-600 (600 MHz) NMR spectrometer equipped with a $\mathrm{TCl} 5 \mathrm{~mm}$ cryoprobe using $\mathrm{CDCl}_{3}$ as a solvent. The solvent signal was used as a reference. Sunfire preparative $\mathrm{C}_{18}$ columns (150 $\times 19 \mathrm{~mm}$, i.d. $5 \mu \mathrm{m}$ and $150 \times 30 \mathrm{~mm}$, i.d. $5 \mu \mathrm{m}$; Waters) were used for preparative HPLC separations using a Waters Delta Prep equipped with a binary pump (Waters 2525) and a UV-visible diode array detector (190-600 nm, Waters 2996). Silica 330 g, 120 g, and 24 g Grace cartridges were used for flash chromatography using an Armen Instrument spot liquid chromatography flash apparatus. Chemicals and solvents were purchased from Sigma-Aldrich. 


\section{Plant material}

The fresh bark of $V$. africana (Yaounde National Herbarium voucher specimen No. HNY/1949; Victor Nana (collector)) was collected from the campus of the University of Yaounde I, Cameroon in December 2019.

\section{Extraction and isolation}

The air-dried and powdered bark of $V$. africana $(2.3 \mathrm{~kg})$ was extracted three times with $\mathrm{MeOH}$ at room temperature. The resulting extract

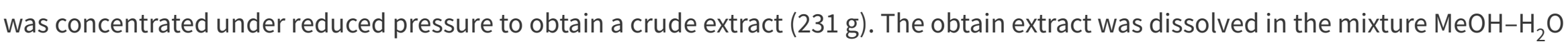
$10 \%$ and alkalinized with $\mathrm{NH}_{3}(\mathrm{pH}=12)$ and extracted with $\mathrm{CH}_{2} \mathrm{Cl}_{2}\left(3 \times 1.5 \mathrm{~L}, 1 \mathrm{~h}\right.$ each, $20^{\circ} \mathrm{C}$, atmospheric pressure). The mixture was concentrated under vacuum at $38^{\circ} \mathrm{C}$ to yield $50.5 \mathrm{~g}$ of an alkaloid extract. A part of this residue (VADCM, $25 \mathrm{~g}$ ) was subjected to flash chromatography using a silica $330 \mathrm{~g}$ Grace cartridge with a gradient of $\mathrm{CH}_{2} \mathrm{Cl}_{2}-\mathrm{MeOH}(100: 0$ to $0: 100)$ at $80 \mathrm{~mL} \mathrm{~min}^{-1}$ to afford fifteen fractions, VA1-VA15, according to their TLC profiles. Fractions VA4-VA6 were gathered $(14.7 \mathrm{~g})$ and were subjected to a second flash chromatography using a silica $120 \mathrm{~g}$ Grace cartridge with a gradient of $\mathrm{CH}_{2} \mathrm{Cl}_{2}-\mathrm{MeOH}(100: 0$ to $0: 100)$ at $80 \mathrm{~mL} \mathrm{~min}^{-1}$ to afford thirteen fractions VAB1-VAB13. Among them, VAB6 (1.7 g) was selected for further fractionation and submitted to Sephadex LH20 and eluted with a mixture of $\mathrm{MeOH}: \mathrm{CH}_{2} \mathrm{Cl}_{2}(8: 2)$ to afford fifteen fractions VAB61-VAB615. VAB67 (761 mg) was submitted again to Sephadex LH-20 (4 cm $\times 90 \mathrm{~cm})$ and eluted with a mixture of $\mathrm{MeOH}: \mathrm{CH}_{2} \mathrm{Cl}_{2}(8: 2)$ to afford thirteen fractions VAB671-VAB6713. VAB6713 underwent a preparative HPLC separation using a gradient of $\mathrm{MeOH}-\mathrm{H}_{2} \mathrm{O}$ with $0.1 \%$ formic acid (grad $10-80 \%$ in $25 \mathrm{~min}$ ) to give compound $\mathbf{1}$ (3.2 $\mathrm{mg}$, yield $0.0005 \%)$.

\section{Physical and spectroscopic data of 1}

Pyrrovobasine (1). Brown amorphous solid; $[\alpha]^{25.0}+160(c 0.05, \mathrm{MeOH}) ; \mathrm{IR} v_{\max } 3400,1720 \mathrm{~cm}^{-1}$; UV (MeOH) $\lambda_{\max }(\log \varepsilon) 232(2.42)$, 296.1 (3.3) nm; ${ }^{1} \mathrm{H}$ and ${ }^{13} \mathrm{C}$ NMR data, see Table 1; HR-ESI-MS m/z 605.3122 [M + H] ${ }^{+}$(calcd for $\left.\mathrm{C}_{37} \mathrm{H}_{41} \mathrm{~N}_{4} \mathrm{O}_{4}, 605.3122\right)$; MS/MS spectrum was 
deposited in the GNPS spectral library under the identifier: CCMSLIB00006710432.

Table $1^{1} \mathrm{H}$ and ${ }^{13} \mathrm{C}$ NMR Data for $\mathbf{1}\left(\mathrm{CDCl}_{3}, 600 / 150 \mathrm{MHz}\right)$

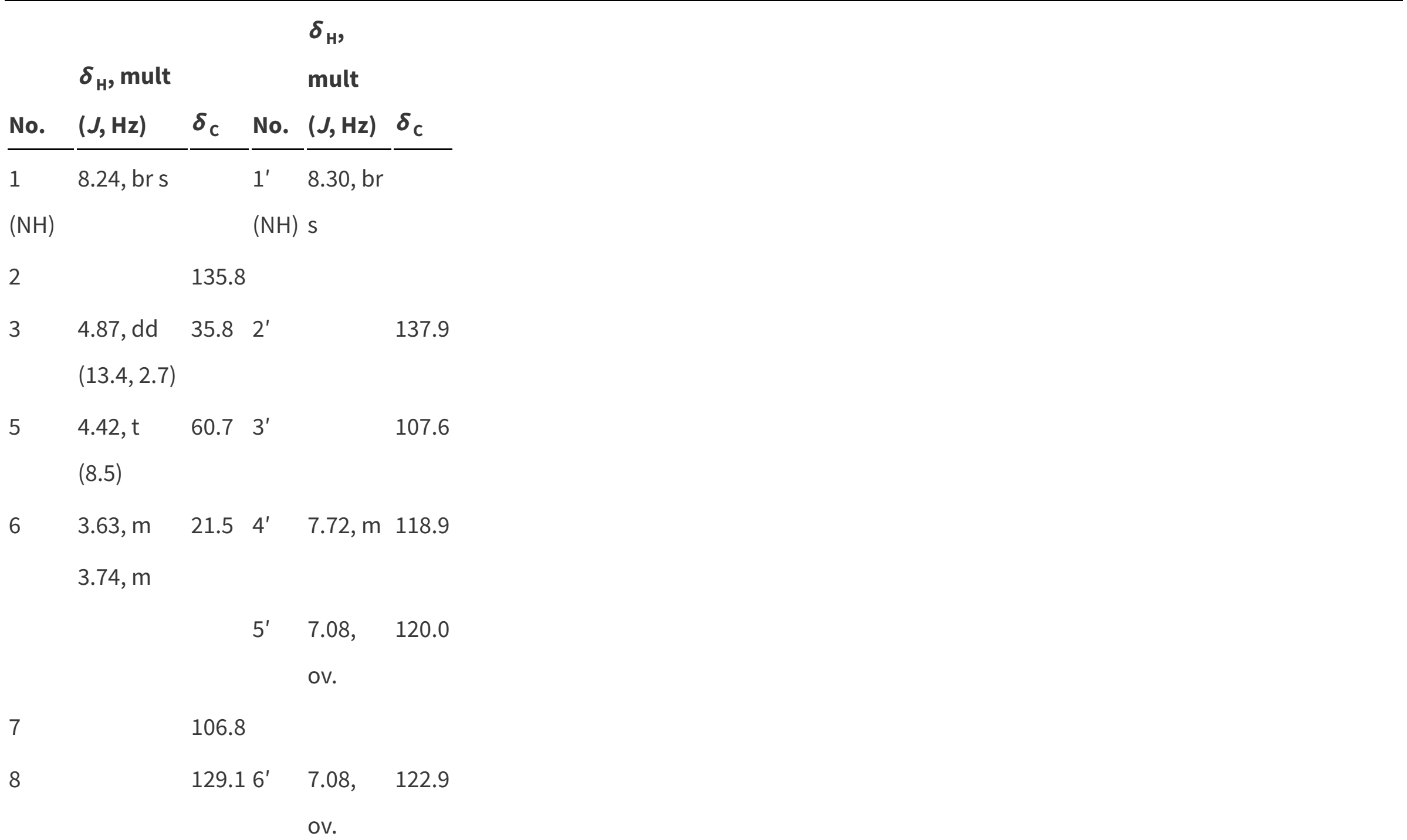




\begin{tabular}{|c|c|c|c|c|c|}
\hline No. & $\begin{array}{l}\delta_{\mathrm{H}}, \text { mult } \\
(\mathrm{J}, \mathrm{Hz})\end{array}$ & $\delta_{c}$ & No. & $\begin{array}{l}\boldsymbol{\delta}_{\mathrm{H}}, \\
\text { mult } \\
(\mathrm{J}, \mathrm{Hz})\end{array}$ & $\boldsymbol{\delta}_{\mathrm{c}}$ \\
\hline 9 & $\begin{array}{l}7.55, d \\
(7.7)\end{array}$ & \multicolumn{2}{|l|}{117.7} & & \\
\hline 10 & 7.11, ov. & \multicolumn{2}{|c|}{$120.07^{\prime}$} & $\begin{array}{l}7.16, \\
\text { ov. }\end{array}$ & 110.8 \\
\hline 11 & 7.15 , ov. & \multicolumn{2}{|c|}{$122.98^{\prime}$} & & 128.4 \\
\hline 12 & 7.16, ov. & \multicolumn{2}{|c|}{$110.89^{\prime}$} & & 135.8 \\
\hline 13 & & \multicolumn{2}{|c|}{$136.4 a$} & $3.42, \mathrm{~m}$ & 26.7 \\
\hline 14 & $\begin{array}{l}2.02, \mathrm{ddd} \\
(15.0,6.7, \\
3.1) \\
2.75, \mathrm{q} \\
(13.4)\end{array}$ & 35.2 & $\beta$ & $\begin{array}{l}4.84, \mathrm{dd} \\
(13.7, \\
6.7)\end{array}$ & 46.9 \\
\hline 15 & $3.89, \mathrm{~m}$ & 32.5 & $2^{\prime \prime}$ & & 132.9 \\
\hline 16 & $2.99, \mathrm{brs}$ & 43.8 & $3^{\prime \prime}$ & $\begin{array}{l}6.97, d \\
(3.9)\end{array}$ & 124.3 \\
\hline & & & $4^{\prime \prime}$ & $\begin{array}{l}6.30, d \\
(3.9)\end{array}$ & 110.7 \\
\hline
\end{tabular}




\begin{tabular}{|c|c|c|c|c|c|}
\hline \multirow[b]{2}{*}{ No. } & $\delta_{H}$, mult & & & $\begin{array}{l}\delta_{\mathrm{H}}, \\
\text { mult }\end{array}$ & \\
\hline & $(J, H z)$ & $\boldsymbol{\delta}_{\mathrm{c}}$ & No. & $(J, \mathrm{~Hz})$ & $\boldsymbol{\delta}_{\mathrm{c}}$ \\
\hline \multirow[t]{4}{*}{18} & $1.73, \mathrm{~d}$ & 13.0 & $5^{\prime \prime}$ & & 141.9 \\
\hline & (6.9) & & & & \\
\hline & & & $6^{\prime \prime}$ & $4.63, d$ & 56.7 \\
\hline & & & & $(13.5)$ & \\
\hline \multirow[t]{3}{*}{19} & $5.60, q$ & 126.6 & & $4.67, d$ & \\
\hline & $(6.9)$ & & & (13.5) & \\
\hline & & & $7^{\prime \prime}$ & $9.56, \mathrm{~s}$ & 179.9 \\
\hline 20 & & 132.9 & & & \\
\hline \multirow[t]{3}{*}{21} & $4.23, \mathrm{~d}$ & 51.4 & & & \\
\hline & $(13.7)$ & & & & \\
\hline & 3.45, ov. & & & & \\
\hline$\underline{\mathrm{C}}$ & & 169.2 & & & \\
\hline OOM & & & & & \\
\hline
\end{tabular}

$\mathrm{COO} 2.49, \mathrm{~s} \quad 51.0$

$\underline{\mathrm{Me}}$

$\mathrm{N}-\mathrm{Me} \quad 2.89, \mathrm{~s} \quad 40.5$ 


\section{Data dependent LC-HRMS² analyses}

LC-ESI-HRMS ${ }^{2}$ analyses were achieved by coupling the LC system to a hybrid quadrupole time of-flight mass spectrometer Agilent 6530 (Agilent Technologies, Massy, France) equipped with an ESII source, operating in positive-ion mode. Source parameters were set as follows: capillary temperature at $320^{\circ} \mathrm{C}$, source voltage at $3500 \mathrm{~V}$, sheath gas flow rate at $10 \mathrm{~L} \mathrm{~min}^{-1}$. The divert valve was set to waste for the first $3 \mathrm{~min}$. MS scans were operated in full-scan mode from $\mathrm{m} / \mathrm{z} 100$ to 1700 ( $0.1 \mathrm{~s} \mathrm{scan}$ time) with a mass resolution of 11000 at $m / z$ 922. $\mathrm{MS}^{1}$ scan was followed by $\mathrm{MS}^{2}$ scans of the three most intense ions above an absolute threshold of 5000 counts. Selected parent ions were fragmented with on collision energie fixed at $50 \mathrm{eV}$ and an isolation window of $1.3 \mathrm{amu}$. Calibration solution, containing two internal reference masses (purine, $\mathrm{C}_{5} \mathrm{H}_{4} \mathrm{~N}_{4}, m / z 121.050873$, and HP-921 [hexakis-( $1 \mathrm{H}, 1 \mathrm{H}, 3 \mathrm{H}$-tetrafluoropentoxy)phosphazene], $\mathrm{C}_{18} \mathrm{H}_{18} \mathrm{O}_{6} \mathrm{~N}_{3} \mathrm{P}_{3} \mathrm{~F}_{24}$, $\mathrm{m} / \mathrm{z}$ 922.0098). A permanent MS/MS exclusion list criterion was set to prevent oversampling of the internal calibrants. LC-UV and MS data acquisition and processing were performed using MassHunter Workstation software (Agilent Technologies, Massy, France).

\section{Molecular networking}

The MS2 data files related to the alkaloid extract of the barks of $V$. africana were converted from the .d (Agilent) standard data-format to .mzXML format using the MSConvert software, part of the ProteoWizard package. $\underline{39} \mathrm{~A}$ molecular network was created using the online Molecular Networking workflow (version release_8) at GNPS표 (http://gnps.ucsd.edu) with a parent mass tolerance of 0.02 Da and a MS/MS fragment ion tolerance of 0.02 Da. A network was then created where edges were filtered to have a cosine score above 0.65 and more than 6 matched peaks. Further edges between two nodes were kept in the network if and only if each of the nodes appeared in each other's respective top 10 most similar nodes. The spectra in the network were then searched against GNPS spectral libraries. All matches kept between network spectra and library spectra were required to have a score above 0.6 and at least 6 matched peaks. The molecular networking data were analyzed and visualized using Cytoscape (ver. 3.6.0). $\underline{40}$

\section{Computational methods}


The lowest energy conformer of compound 1 was fully optimized in vacuo and without constraint using DFT $\underline{41,42}$ with the hybrid Becke-3parameter-Lee-Yang-Parr $\underline{43}, \underline{44}$ exchange-correlation functional and the 6-31G* basis,,$\underline{45}$ as implemented in the Gaussian 16 revB.01 software package. $\underline{46}$ Upon geometrical optimization convergence, a frequency calculation within the harmonic approximation was conducted at the same level of theory and conformer was characterized as a minimum by the absence of imaginary frequency. TDDFT at the same level of theory was then employed to predict energies as well as rotational strengths of the first 60 electronic transitions. The UCSF Chimera v1.11프 software package was used for the depiction of the most stable conformer of compound 1. ECD spectrum envelope was then calculated using SpecDis v1.71프 using sigma/gamma value of $0.2 \mathrm{eV}$ and a shift of $+14 \mathrm{~nm}$ and rendered using Gnuplot v5.2. .99

\section{Biological evaluation}

Antibacterial activity assay by microdilutions. The antibacterial activity was assessed as previously described $\underline{50}$ against Staphylococcus aureus (ATCC 6538), Pseudomonas aeruginosa (ATCC 15442), Mycobacterium smegmatis (CIP 7326) and Mycobactrium abscessus (M. abscessus subsp. bolletii, ITM-M001006, BCCM, Belgium). The assays were performed in 96-well plates using a broth microdilution method in order to identify the minimal inhibitory concentration (MIC). Two-fold serial dilutions (100 $\mu \mathrm{L}$ in $200 \mu \mathrm{L}$ final volume) of the molecules were first performed in triplicates in Mueller Hinton broth (or in the 7H9 medium when working with $M$. abscessus). Then, $100 \mu \mathrm{L}$ bacteria (100 fold dilution of $0.5 \mathrm{Mc}$ Farland) were added into each well. Negative (without bacteria) and positive (without additional compounds) controls were present in each plate. The MIC value were first interpreted after $24 \mathrm{~h}$ incubation at $37^{\circ} \mathrm{C}$ (or 2-3 days incubation for M. abscessus), corresponding to the lowest concentration inhibiting bacteria growth after visual inspection. This visual interpretation was always verified by adding MTT reagent, 3-(4,5-dimethylthiazol-2-yl)-2,5-diphenyltetrazolium bromide, (0.5 mg $\mathrm{mL}^{-1}$ final concentration) to allow formazan crystal formation in viable cells during $4 \mathrm{~h}$ additional incubation period. A final naked eye inspection was performed to record the results. This assay was performed in triplicate in three separate experiments. Positive control drugs were vancomycin hydrochloride for Staphylococcus aureus, cetrimide for Pseudomonas aeruginosa, and rifampicin for Mycobacterium smegmatis. 
Activity assay against $\boldsymbol{M}$. bovis BCG. To assess the antimycobacterial activity of our compounds on M. bovis BCG, the MIC was assessed by the microdilution method as previously described, $\underline{51}$ performed in $7 \mathrm{H} 9$ medium supplemented with $10 \%$ albumin-dextrose complex and $0.2 \%$ glycerol in a polycarbonate tube to reach a final volume of $1 \mathrm{ml}$. Briefly, $0.5 \mathrm{~mL}$ of 2-fold serial drug dilutions were inoculated with $0.5 \mathrm{~mL}$ (at $5 \times 10^{5} \mathrm{CFU}$ per mL) early exponential culture. Vancomycin at a final concentration of $25 \mu \mathrm{g} \mathrm{mL}$ (far under its MIC > $500 \mathrm{mg} \mathrm{mL}^{-1}$ ) was eventually added to investigate the possible synergy between the two drugs. The MIC was interpreted as the lowest drug concentration that inhibited visible bacterial growth, defined by clump formation, when growth of the $1 \%$ inoculum drugfree control became visible (after 5-10 days growth).

The antimycobacterial activity was further assessed to investigate whether at the MIC, compounds could have an irreversible antimycobacterial activity (bactericidal activity) or a reversible effect (bacteriostatic activity) on M. bovis BCG. This was assessed by spreading $10 \mu \mathrm{L}$ out of the $1 \mathrm{~mL}$ tubes from the broth microdilution method on $7 \mathrm{H} 11$ agar plate. Proliferation of bacteria colonies was interpreted as bacteria having encountered mycobacteriostatic compounds at their MIC, while absence of proliferation was interpreted as bacteria having encountered mycobactericidal compounds at their MBC (minimal bactericidal concentration).

\section{Author contributions}

The manuscript was written through contributions of all authors. All authors have given approval to the final version of the manuscript.

\section{Conflicts of interest}

There are no conflicts to declare.

\section{Acknowledgements}


We are very grateful to OPCW (Organisation for the Prohibition of Chemical Weapons) for the postdoctoral fellowship of $\mathrm{H}$. F. and the financial support from ARES-CCD (Belgium). In addition, this work was supported by the French ANR grant ANR-20-CE43-0010. Leo Goehrs (Alionis) is gratefully acknowledged for the donation of the computing hardware.

\section{Notes and references}

1. Q. Zhao, W.-T. Zhu, X. Ding, Z.-Q. Huo, P. O. Donkor, T. A. Adelakun, X.-J. Hao and Y. Zhang, Voacafrines A-N, aspidosperma-type monoterpenoid indole alkaloids from Voacanga africana with AChE inhibitory activity, Phytochemistry, 2021, 181, 112566 CrossRef CAS PubMed.

2. M. Harada, K. N. Asaba, M. Iwai, N. Kogure, M. Kitajima and H. Takayama, Asymmetric Total Synthesis of an Iboga-Type Indole Alkaloid, Voacangalactone, Newly Isolated from Voacanga africana, Org. Lett., 2012, 14, 5800-5803 CrossRef CAS PubMed.

3. C.-F. Ding, H.-X. Ma, J. Yang, X.-J. Qin, G. S. S. Njateng, H.-F. Yu, X. Wei, Y.-P. Liu, W.-Y. Huang, Z.-F. Yang, X.-H. Wang and X.-D. Luo, Antibacterial Indole Alkaloids with Complex Heterocycles from Voacanga africana, Org. Lett., 2018, 20, 27022706 CrossRef CAS PubMed.

4. M. A. Beniddir, K. B. Kang, G. Genta-Jouve, F. Huber, S. Rogers and J. J. J. van der Hooft, , Advances in decomposing complex metabolite mixtures using substructure- and network-based computational metabolomics approaches, Nat. Prod. Rep., 2021 10.1039/D1NP00023C.

5. A. E. Fox Ramos, L. Evanno, E. Poupon, P. Champy and M. A. Beniddir, Natural products targeting strategies involving molecular networking: different manners, one goal, Nat. Prod. Rep., 2019, 36, 960-980 RSC.

6. E. Otogo N'Nang, P. Le Pogam, T. Ndong Mba, C. Sima Obiang, E. Mouray, P. Grellier, B. Kumulungui, P. Champy and M. A. Beniddir, Targeted Isolation of Hemitheion from Mostuea brunonis, a Proposed Biosynthetic Intermediate of Theionbrunonines, J. Nat. Prod., 2021, 84, 1409-1413 CrossRef. 
7. T. Kouamé, G. Bernadat, V. Turpin, M. Litaudon, A. T. Okpekon, J.-F. Gallard, K. Leblanc, S. Rharrabti, P. Champy, E. Poupon, M. A. Beniddir and P. Le Pogam, Structure Reassignment of Melonine and Quantum-Chemical Calculations-Based Assessment of Biosynthetic Scenarios Leading to Its Revised and Original Structures, Org. Lett., 2021, 23, 5964-5968 CrossRef.

8. C. F. Alcover, G. Bernadat, F. A. Kabran, P. Le Pogam, K. Leblanc, A. E. Fox Ramos, J.-F. Gallard, E. Mouray, P. Grellier, E. Poupon and M. A. Beniddir, Molecular Networking Reveals Serpentinine-Related Bisindole Alkaloids from Picralima nitida, a Previously WellInvestigated Species, J. Nat. Prod., 2020, 83, 1207-1216 CrossRef CAS.

9. T. Kouamé, A. T. Okpekon, N. F. Bony, A. D. N'Tamon, J.-F. Gallard, S. Rharrabti, K. Leblanc, E. Mouray, P. Grellier, P. Champy, M. A. Beniddir and P. Le Pogam, Corynanthean-Epicatechin Flavoalkaloids from Corynanthe pachyceras, Molecules, 2020, 25, 2654 CrossRef.

10. G. Cauchie, E. O. N'Nang, J. J. J. van der Hooft, P. Le Pogam, G. Bernadat, J.-F. Gallard, B. Kumulungui, P. Champy, E. Poupon and M. A. Beniddir, Phenylpropane as an Alternative Dearomatizing Unit of Indoles: Discovery of Inaequalisines A and B Using Substructure-Informed Molecular Networking, Org. Lett., 2020, 22, 6077-6081 CrossRef CAS.

11. A. D. N'Tamon, A. T. Okpekon, N. F. Bony, G. Bernadat, J.-F. Gallard, T. Kouamé, B. Séon-Méniel, K. Leblanc, S. Rharrabti, E. Mouray, P. Grellier, M. Ake, N. C. C. Amin, P. Champy, M. A. Beniddir and P. Le Pogam, Streamlined targeting of Amaryllidaceae alkaloids from the bulbs of Crinum scillifolium using spectrometric and taxonomically-informed scoring metabolite annotations, Phytochemistry, 2020, 179, 112485 CrossRef PubMed.

12. A. E. Fox Ramos, C. Pavesi, M. Litaudon, V. Dumontet, E. Poupon, P. Champy, G. Genta-Jouve and M. A. Beniddir, CANPA: ComputerAssisted Natural Products Anticipation, Anal. Chem., 2019, 91, 11247-11252 CrossRef CAS PubMed.

13. A. E. Fox Ramos, P. Le Pogam, C. Fox Alcover, E. Otogo N'Nang, G. Cauchie, H. Hazni, K. Awang, D. Bréard, A. M. Echavarren, M. Frédérich, T. Gaslonde, M. Girardot, R. Grougnet, M. S. Kirillova, M. Kritsanida, C. Lémus, A.-M. Le Ray, G. Lewin, M. Litaudon, L. Mambu, S. Michel, F. M. Miloserdov, M. E. Muratore, P. Richomme-Peniguel, F. Roussi, L. Evanno, E. Poupon, P. Champy and M. A. 
Beniddir, Collected mass spectrometry data on monoterpene indole alkaloids from natural product chemistry research, Sci. Data, 2019, 6, 15 CrossRef.

14. G. Baudouin, F. Tillequin, M. Bert and M. Koch, Ceridimine: a novel type of bisindole monoterpene alkaloid, J. Chem. Soc., Chem. Commun., 1986, 3-4 RSC.

15. T.-S. Kam and Y.-M. Choo, in The Alkaloids: Chemistry and Biology, ed. G. A. Cordell, Academic Press, 2006, vol. 63, pp. 181337 Search PubMed.

16. M. Kitajima and H. Takayama, in The Alkaloids: Chemistry and Biology, ed. H.-J. Knölker, Academic Press, 2016, vol. 76, pp. 259310 Search PubMed.

17. M. Wang, J. J. Carver, V. V. Phelan, L. M. Sanchez, N. Garg, Y. Peng, D. D. Nguyen, J. Watrous, C. A. Kapono, T. Luzzatto-Knaan, C. Porto, A. Bouslimani, A. V. Melnik, M. J. Meehan, W.-T. Liu, M. Crusemann, P. D. Boudreau, E. Esquenazi, M. Sandoval-Calderon, R. D. Kersten, L. A. Pace, R. A. Quinn, K. R. Duncan, C.-C. Hsu, D. J. Floros, R. G. Gavilan, K. Kleigrewe, T. Northen, R. J. Dutton, D. Parrot, E. E. Carlson, B. Aigle, C. F. Michelsen, L. Jelsbak, C. Sohlenkamp, P. Pevzner, A. Edlund, J. McLean, J. Piel, B. T. Murphy, L. Gerwick, C.C. Liaw, Y.-L. Yang, H.-U. Humpf, M. Maansson, R. A. Keyzers, A. C. Sims, A. R. Johnson, A. M. Sidebottom, B. E. Sedio, A. Klitgaard, C. B. Larson, C. A. Boya P, D. Torres-Mendoza, D. J. Gonzalez, D. B. Silva, L. M. Marques, D. P. Demarque, E. Pociute, E. C. O'Neill, E. Briand, E. J. N. Helfrich, E. A. Granatosky, E. Glukhov, F. Ryffel, H. Houson, H. Mohimani, J. J. Kharbush, Y. Zeng, J. A. Vorholt, K. L. Kurita, P. Charusanti, K. L. McPhail, K. F. Nielsen, L. Vuong, M. Elfeki, M. F. Traxler, N. Engene, N. Koyama, O. B. Vining, R. Baric, R. R. Silva, S. J. Mascuch, S. Tomasi, S. Jenkins, V. Macherla, T. Hoffman, V. Agarwal, P. G. Williams, J. Dai, R. Neupane, J. Gurr, A. M. C. Rodriguez, A. Lamsa, C. Zhang, K. Dorrestein, B. M. Duggan, J. Almaliti, P.-M. Allard, P. Phapale, L.-F. Nothias, T. Alexandrov, M. Litaudon, J.-L. Wolfender, J. E. Kyle, T. O. Metz, T. Peryea, D.-T. Nguyen, D. VanLeer, P. Shinn, A. Jadhav, R. Muller, K. M. Waters, W. Shi, X. Liu, L. Zhang, R. Knight, P. R. Jensen, B. O. Palsson, K. Pogliano, R. G. Linington, M. Gutierrez, N. P. Lopes, W. H. Gerwick, B. S. Moore, P. C. Dorrestein and N. Bandeira, Sharing and community curation of mass spectrometry data with Global Natural Products Social Molecular Networking, Nat. Biotechnol., 2016, 34, 828-837 CrossRef CAS. 
18. DNP http://dnp.chemnetbase.com/ (accessed Aug 27, 2021).

19. H. Takayama, S. Suda, I.-S. Chen, M. Kitajima, N. Aimi and S.-i. Sakai, Two New Dimeric Indole Alkaloids from Tabernaemontana subglobosa Merr. from Taiwan, Chem. Pharm. Bull., 1994, 42, 280-284 CrossRef CAS.

20. M. Azoug, A. Loukaci, B. Richard, J.-M. Nuzillard, C. Moreti, M. Zèches-Hanrot and L. Le Men-Olivier, Alkaloids from stem bark and leaves of Peschiera buchtieni, Phytochemistry, 1995, 39, 1223-1228 CrossRef CAS.

21. S. Subhadhirasakul, H. Takayama, Y. Miyabe, M. Kitajima, D. Ponglux, S.-i. Sakai and N. Aimi, Two novel sarpagine-type indole alkaloids from the leaves of Hunteria zeylanica in Thailand, Heterocycles, 1995, 9, 2049-2056 Search PubMed.

22. T.-S. Kam and K.-M. Sim, Conodurine, conoduramine, and ervahanine derivatives from Tabernaemontana corymbosa, Phytochemistry, 2003, 63, 625-629 CrossRef CAS PubMed.

23. C. Zhang, Y. Idelbayev, N. Roberts, Y. Tao, Y. Nannapaneni, B. M. Duggan, J. Min, E. C. Lin, E. C. Gerwick, G. W. Cottrell and W. H. Gerwick, Small Molecule Accurate Recognition Technology (SMART) to Enhance Natural Products Research, Sci. Rep., 2017, 7, 14243 CrossRef PubMed.

24. R. Reher, H. W. Kim, C. Zhang, H. H. Mao, M. Wang, L.-F. Nothias, A. M. Caraballo-Rodriguez, E. Glukhov, B. Teke, T. Leao, K. L. Alexander, B. M. Duggan, E. L. Van Everbroeck, P. C. Dorrestein, G. W. Cottrell and W. H. Gerwick, A Convolutional Neural NetworkBased Approach for the Rapid Annotation of Molecularly Diverse Natural Products, J. Am. Chem. Soc., 2020, 142, 41144120 CrossRef CAS PubMed.

25. T. M. Zennie, J. M. Cassady and R. F. Raffauf, Funebral, a New Pyrrole Lactone Alkaloid from Quararibea funebris, J. Nat. Prod., 1986, 49, 695-698 CrossRef CAS.

26. N. Harada and K. Nakanishi, Exciton chirality method and its application to configurational and conformational studies of natural products, Acc. Chem. Res., 1972, 5, 257-263 CrossRef CAS.

27. A. E. Nugroho, Y. Hirasawa, N. Kawahara, Y. Goda, K. Awang, A. H. A. Hadi and H. Morita, Bisnicalaterine A, a Vobasine-Vobasine Bisindole Alkaloid from Hunteria zeylanica, J. Nat. Prod., 2009, 72, 1502-1506 CrossRef CAS. 
28. J. Xu, Y. C. Song, Y. Guo, Y. N. Mei and R. X. Tan, Fumigaclavines D-H, New Ergot Alkaloids from Endophytic Aspergillus fumigatus, Planta Med., 2014, 80, 1131-1137 CrossRef CAS.

29. C. K. Narkowicz, A. J. Blackman, E. Lacey, J. H. Gill and K. Heiland, Convolutindole A and Convolutamine H, New Nematocidal Brominated Alkaloids from the Marine Bryozoan Amathia convoluta, J. Nat. Prod., 2002, 65, 938-941 CrossRef CAS.

30. L. S. Mulwa, R. Jansen, D. F. Praditya, K. I. Mohr, J. Wink, E. Steinmann and M. Stadler, Six Heterocyclic Metabolites from the Myxobacterium Labilithrix luteola, Molecules, 2018, 23, 542 CrossRef.

31. T. A. Foderaro, L. R. Barrows, P. Lassota and C. M. Ireland, Bengacarboline, a New $\beta$-Carboline from a Marine Ascidian Didemnum sp., J. Chem. Org., 1997, 62, 6064-6065 CrossRef CAS.

32. A. M. Wolters, D. A. Jayawickrama and J. V. Sweedler, Comparative Analysis of a Neurotoxin from Calliostoma canaliculatum by OnLine Capillary Isotachophoresis/H NMR and Diffusion ${ }^{1}$ H NMR, J. Nat. Prod., 2005, 68, 162-167 CrossRef CAS PubMed.

33. C. T. Walsh, Biological Matching of Chemical Reactivity: Pairing Indole Nucleophilicity with Electrophilic Isoprenoids, ACS Chem. Biol., 2014, 9, 2718-2728 CrossRef CAS.

34. M. E. Tanner, Mechanistic studies on the indole prenyltransferases, Nat. Prod. Rep., 2015, 32, 88-101 RSC.

35. J. M. Wood, D. P. Furkert and M. A. Brimble, 2-Formylpyrrole natural products: origin, structural diversity, bioactivity and synthesis, Nat. Prod. Rep., 2019, 36, 289-306 RSC.

36. M. Hellwig and T. Henle, Baking, Ageing, Diabetes: A Short History of the Maillard Reaction, Angew. Chem., Int. Ed., 2014, 53, 1031610329 CrossRef CAS.

37. W.-G. Shan, Y. Wang, L.-F. Ma and Z.-J. Zhan, A new pyrrole alkaloid from the mycelium of Inonotus obliquus, J. Chem. Res., 2017, 41, 392-393 CrossRef CAS.

38. Z. Sun, M. Hu, Z. Sun, N. Zhu, J. Yang, G. Ma and X. Xu, Pyrrole Alkaloids from the Edible Mushroom Phlebopus portentosus with Their Bioactive Activities, Molecules, 2018, 23, 1198 CrossRef. 
39. M. C. Chambers, B. Maclean, R. Burke, D. Amodei, D. L. Ruderman, S. Neumann, L. Gatto, B. Fischer, B. Pratt, J. Egertson, K. Hoff, D. Kessner, N. Tasman, N. Shulman, B. Frewen, T. A. Baker, M.-Y. Brusniak, C. Paulse, D. Creasy, L. Flashner, K. Kani, C. Moulding, S. L. Seymour, L. M. Nuwaysir, B. Lefebvre, F. Kuhlmann, J. Roark, P. Rainer, S. Detlev, T. Hemenway, A. Huhmer, J. Langridge, B. Connolly, T. Chadick, K. Holly, J. Eckels, E. W. Deutsch, R. L. Moritz, J. E. Katz, D. B. Agus, M. MacCoss, D. L. Tabb and P. Mallick, A crossplatform toolkit for mass spectrometry and proteomics, Nat. Biotechnol., 2012, 30, 918-920 CrossRef CAS.

40. P. Shannon, A. Markiel, O. Ozier, N. S. Baliga, J. T. Wang, D. Ramage, N. Amin, B. Schwikowski and T. Ideker, Cytoscape: A Software Environment for Integrated Models of Biomolecular Interaction Networks, Genome Res., 2003, 13, 2498-2504 CrossRef CAS.

41. P. Hohenberg and W. Kohn, Inhomogeneous Electron Gas, Phys. Rev., 1964, 136, B864-B871 CrossRef.

42. W. Kohn and L. J. Sham, Self-Consistent Equations Including Exchange and Correlation Effects, Phys. Rev. [Sect.] B, 1965, 140, A1133-A1138 CrossRef.

43. A. D. Becke, Density-functional thermochemistry. III. The role of exact exchange, J. Chem. Phys., 1993, 98, 5648-5652 CrossRef CAS.

44. C. Lee, W. Yang and R. G. Parr, Development of the Colle-Salvetti correlation-energy formula into a functional of the electron density, Phys. Rev. B: Condens. Matter Mater. Phys., 1988, 37, 785-789 CrossRef CAS.

45. W. J. R. Hehre, L. Radom, P. V. R. Schleyer and J. A. Pople, AB Initio Molecular Orbital Theory, Wiley, New York, 1986 Search PubMed.

46. M. J. Frisch, H. B. Trucks, G. W. Schlegel, G. E. Scuseria, M. A. Robb, J. R. Cheeseman, G. Scalmani, V. Barone, G. A. Petersson and H. Nakatsuji, et al. Gaussian 16 Revision B.01, Gaussian Inc., Wallingford, CT, USA, 2016 Search PubMed.

47. E. F. Pettersen, T. D. Goddard, C. C. Huang, G. S. Couch, D. M. Greenblatt, E. C. Meng and T. E. Ferrin, UCSF Chimera-A visualization system for exploratory research and analysis, J. Comput. Chem., 2004, 25, 1605-1612 CrossRef CAS PubMed.

48. T. Bruhn, A. Schaumlöffel, Y. Hemberger and G. Bringmann, SpecDis: Quantifying the Comparison of Calculated and Experimental Electronic Circular Dichroism Spectra, Chirality, 2013, 25, 243-249 CrossRef CAS. 
49. H. B. Bröker, J. Campbell, R. Cunningham, D. Denholm, G. Elber, R. Fearick, C. Grammes, L. Hart, L. Heckingu and P. Juhász, Gnuplot 4.6: an Interactive Plotting Program, http://gnuplot.sourceforge.net/ Search PubMed.

50. S. Oliveira Ribeiro, V. Fontaine, V. Mathieu, A. Zhiri, D. Baudoux, C. Stévigny and F. Souard, Antibacterial and Cytotoxic Activities of Ten Commercially Available Essential Oils, Antibiotics, 2020, 9, 717 CrossRef.

51. C. Rens, F. Laval, M. Daffé, O. Denis, R. Frita, A. Baulard, R. Wattiez, P. Lefèvre and V. Fontaine, Effects of Lipid-Lowering Drugs on Vancomycin Susceptibility of Mycobacteria, Antimicrob. Agents Chemother., 2016, 60, 6193-6199 CrossRef CAS.

\section{Footnote}

† Electronic supplementary information (ESI) available: Cartesian coordinates, HRMS, and NMR data of 1. See DOI: 10.1039/d1ob01791h

\section{This journal is @ The Royal Society of Chemistry 2022}

